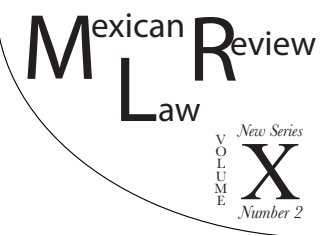

\title{
THE APPLIGATION OF BLANK CRIMINAL LAW AND THE PRINCIPLE OF LEGALITY: THE GUATEMALAN EXAMPLE
}

\author{
Lucas MartíneZ-VILLALbA*
}

\begin{abstract}
The following article aims to assess the applicability of "blank criminal laws" under positive legal systems, as well as the threat it represents for the nullum crimen sine lege principle. It discusses the approaches to this concept taken by different legal systems in Latin America, particularly in Guatemala, where this technique was recently used to include in a flagship sentence several Conventions in which the State is involved but which are not fully transcribed into the corresponding codes. "Blank criminal lawe" are understood as incomplete laws that only establish a penalty, leaving it to another judicial rule the broader definition, and analysis. The article compares the application of such laws in different Latin American countries, and how each country addresses the possible collision with the principle of legality.
\end{abstract}

Key Words: Blank criminal law, principle of legality or criminality, Constitutional Court, war crimes, crimes against humanity, criminal conduct.

RESUmen: El presente ensayo pretende evaluar la aplicabilidad del derecho penal en blanco en el marco de los sistemas jurídicos de naturaleza positiva, particularmente el conflicto que tal aplicación representaría frente al principio de legalidad. El articulo expone las distintas aproximaciones realizadas por destacadas legislaciones en América Latina, acentuando el caso de Guatemala, donde esta técnica legislativa fue recientemente usada para incluir, en una decisión emblemática, el contenido de distintos tratados de los que el Estado forma parte, pero que no aparecen completamente descritos en su legislación penal. De esta manera, el artículo compara la aplicación del derecho penal en blanco en distintos sistemas legales en América Latina y la manera en que estos se enfrentan a la posible contradicción con el principio de legalidad. En los términos del presente ensayo, una ley penal en blanco consiste en aquellas leyes incompletas, que se limitan a fijar una determinada sanción, dejando a otra norma jurídica la misión de completarla con la determinación del precepto.

* SJD Candidate Washington College of Law. LL.M in International Legal Studies, Washington College of Law; LL. M. in Human Rights, Universidad Iberoamericana; LL. B., Pontificia Universidad Javeriana. 
Esta revista forma parte del acervo de la Biblioteca Jurídica Virtual del Instituto de Investigaciones Jurídicas de la UNAM

Palabras Clave: Derecho penal en blanco, principio de legalidad, Corte Constitucional, crímenes de guerra, crímenes de la humanidad, conducta penal.

Table of Contents

I. INTRODUCTION 68

II. Analysis of the Nullum Crimen Principle.

III. Blank Griminal Laws as a Legislative Tool

IV. The Application of Blank Criminal Laws in Latin America....

V. Conclusion.

\section{INTRODUCTION}

On Friday, February 26, 2016, The High Risk Court (A) in Guatemala found two former senior military officers guilty of crimes against humanity in a case involving, rape, sexual violence, sexual slavery, inhumane treatment and forced labor under article 378 of the Guatemalan Penal Code. ${ }^{1}$ The mentioned article refers to "Crimes against the Duties of Humanity" and is used to characterize conducts which amount to War Crimes or Crimes Against Humanity. This provision succeeds in grouping all the previously mentioned conducts into one single article applying the technique of blank criminal law (Derecho Penal en Blanco).

The term "blank criminal law" comes from the German word Blankettstrafgesetz. It was first used by Karl Binding in its 1872 work: Die Normen und ihre Ubertretung. Binding defines "blank penal law" as: "those incomplete laws which simply set a certain penalty, leaving the mission to another norm to complete its determination, that is, the specific description of the criminal offense". ${ }^{2}$ In other words, blank criminal laws are those criminal laws that do not fully describe the prohibited conduct. Therefore, they are completed by other laws to fulfill that description.

However, the application of this technique might pose a threat to the principle of nullum crimen sine lege, especially under positive law systems such as Guatemala's. Different systems throughout Latin America have provided diverse approaches regarding the use of blank criminal laws; some of these systems have strongly limited this legislative technique, while others have almost unconditionally accepted its application. The following investigation will

1 The case is commonly known as the Sepur Zarco. See Prensa Libre, Sepur Zarco Reyes Girón 120 y Valdez Asï 240 años de prisión, PRENSA LIBRE (Feb. 26, 2016, 08:41 AM). http://www. prensalibre.com/guatemala/justicia/sepur-zarco---tribunal-dictara-sentencia-esta-tarde.

2 Unofficial translation of: "aquellas leyes incompletas, que se limitan a fijar una determinada sanción, dejando a otra norma jurídica la misión de completarla con la determinación del precepto, o sea, la descripción específica de la conducta punible, In: Álvaro Roberto Delgado Lara, Las leyes penales en blanco en la jurisprudencia del Tribunal Constitucional (2005-2011), 8 No. 2 Ars Boni et Aequi, 277 (2012). 
compare these different approaches and the interpretation given by them to the principle of legality under the existence of blank criminal laws. In other words, it will try to establish the line where what is strictly written as law blurs to allow for the existence of blank criminal laws. Given the unprecedented decision in Guatemala in which two former military officers where convicted for crimes against humanity and war crimes under local courts, the application of blank criminal law may become pivotal as a reference for future trials throughout the region.

\section{Analysis of the Nullum Crimen Principle}

The first challenge blank criminal law faces is the possible contradiction with the principle of legality. The latin formula "nullum crimen sine lege" is attributed to Paul Johann Anselm Feuerbach who came to highlight and specify one of the central achievements of the French Revolution (article 8 of the Declaration of Rights of Man of August 26, 1789, and the Constitution of September 3, 1791). ${ }^{3}$ However, Feuerbach did not literally refer to the $n u l-$ lum crime sine lege, as much as it's interpreted from his reasoning. ${ }^{4}$ Thus, the principle nullum crime sine lege is an approach of Cesare Becaria in his work "On crimes and punishments" in which he explains "laws alone can decree punishments for crimes ...that this authority can rest only with the legislator, who represents all of society united by a social contract."

It is thus important to highlight how the legal system approaches this mentioned principle: It has developed as a rule under international law prohibiting retroactive application of criminal laws. ${ }^{7}$ For instance, it is included in Article 15 of the 1966 International Covenant on Civil and Political Rights (ICGPR). ${ }^{8}$ Specifically, Article 15 provides:

1. No one shall be held guilty of any criminal offence on account of any act or omission that did not constitute a criminal offence, under national or international law, at the time when it was committed.

2. Nothing in this article shall prejudice the trial and punishment of any person for any act or omission that, at the time when it was committed, was criminal according to the general principles of law recognized by the community of nations. ${ }^{9}$

3 S. Mir Puig, Derecho Penal Parte General 26 (Barcelona, 1984).

Id.

5 Cesare Beccaria, On crimes and punishments and other writings 12 (Aaron Thomas and Jeremy Parzen trans., University of Toronto 2008).

${ }^{6} I d$.

7 M. Cherif Bassiouni, The Sources and Content of International Criminal Law: A Theoretical Framework, in International Criminal LAW, 2d rev. ed. vol. 1, ed. M. Cherif Bassiouni (New York: Transnational Publishers, 1999).

8 International Covenant on Civil and Political Rights, Dec. 16, 1966, S. Exec. Rep. 102-23, 999 U.N.T.S. 171. Ratified by the Guatemalan congress through decree 9-92 on 1 May 1992

9 Id. Art. 15. 
The principle is also codified in key human rights treaties, including the African Charter on Human and People's Rights, ${ }^{10}$ the European Convention on Human Rights, ${ }^{11}$ and the American Convention on Human Rights (ACHR). ${ }^{12}$ The relevant provision of the ACHR, Article 9, states: "No one shall be convicted of any act or omission that did not constitute a criminal offense, under the applicable law, at the time it was committed..."13

Importantly, although the ACHR, unlike the ICCPR, does not refer expressly to international law, the Inter-American Court of Human Rights has stated that the purpose of the nullum crimen provision is to safeguard the fundamental rights of life and liberty against arbitrary abuses of power. ${ }^{14}$ Because the international community has long recognized that individuals may be prosecuted for acts committed in violation of international law, ${ }^{15}$ such prosecutions would not constitute an arbitrary abuse of power and thus would be consistent with the principle enshrined in Article 9 of the ACHR.

Notably, international criminal tribunals and the European Court of Human Rights have expressly adopted a flexible approach to the prosecution of crimes that were only codified under customary international law at the time the relevant conduct was committed, recognizing the nature of international law and the severity of crimes that rise to the level of international crimes. For instance, while international criminal tribunals have made clear that the nullum crimen principle requires not only that the conduct was prohibited, but also that it gave rise to individual criminal responsibility under domestic or international law at the time it occurred, ${ }^{16}$ they have also held that the principle

10 See, African Charter on Human Rights and Peoples' Rights, adopted June 27, 1981, 21 I.L.M. 58

11 Convention for the Protection of Human Rights and Fundamental Freedoms, adopted 4 November 1950, 213 U.N.T.S. 221.

12 Organization of American States, American Convention on Human Rights, adopted 22 November 1969, 1144 U.N.T.S. 123.

13 Id. Ratified by Guatemalan on November 22, 1969. Guatemala also recognized the jurisdiction of the Inter-American Court of Human Rights through Government Agreement No. 123-87, dated February 20, 1987

14 See, Case of Ricardo Canese v. Paraguay. Merits, Reparations and Costs. Judgment, Inter-Am. Ct. H.R. (ser. C) No. 111, 174 (Aug. 31, 2004).

15 See, e.g., infra, Section IV. But see also Corte Constitucional de Colombia. Sentencia C-004 de 200334 (M.P. Dr. Eduardo Montealegre Lynett: January 2003). (holding that cases involving human rights violations and serious infringements of international humanitarian law may be re-opened based on evidence that an accused was acquitted due to a failure by the State to adequately and impartially investigate, even though there is no express language in the Colombian Procedural Criminal Code allowing for such a procedure).

16 See, e.g., Prosecutor v. Georges Anderson Nderubumwe Rutaganda, Case No. ICTR-96-3, Judgment and Sentence, 86 ICTR-96-3 (6 December 1999) (supporting the proposition that, in order for the nullum crimen principle to be satisfied, the conduct in question must not only be violative of international law, but also it shoud have given rise to individual criminal responsibility); Prosecutor v. Dusko Tadic, Case No. IT-94-1-AR72, Decision on the Defence Motion for 
does not require that a crime was proscribed in the exact and precise terms in which it is later prosecuted. ${ }^{17}$ Rather, according to the International Criminal Tribunal for the former Yugoslavia (ICTY) and Rwanda (ICTR), as long as individuals could have reasonably foreseen from the law what acts or omissions would entail criminal liability, the nullum crimen principle is satisfied. ${ }^{18}$ Thus, as the ICTY explained in the Hadžihasanović case: "In interpreting the principle of nullum crimen sine lege, it is critical to determine whether the underlying conduct at the time of its commission was punishable. The emphasis on conduct, rather than on the specific description of the offense in substantive criminal law, is of primary relevance." 19

In other words, "the principle of nullum crimen sine lege is satisfied if the underlying criminal conduct as such was punishable, regardless of how the concrete charges in a specific law would have been formulated." ${ }^{20}$ Notably, the European Court of Human Rights has taken a similar approach in interpreting the nullum crimen provision of the European Convention on Human Rights, ${ }^{21}$ which is virtually identical to that found in the ICGPR. ${ }^{22}$

Interlocutory Appeal on Jurisdiction, 128-136 (2 October 1995). At least one human rights body, the European Court of Human Rights, had adopted the same approach: Streletz, Kessler and Krentz v. Germany, (Applications nos. 34044/96, 35532/97 and 44801/98), Judgment (22 March 2001).

17 Prosecutor v. Enver Hadžihasanović, Case No. IT-01-47-PT, Decision on Joint Challenge to Jurisdiction, 62, 165 (12 November 2002); Prosecutor v. Edouard Karemera, et al., Case No. ICTR98-44-T, Decision on the Preliminary Motions by the Defence of Joseph Nzirorera, Édouard Karemera, André Rwamakuba and Mathieu Ngirumpatse Challenging Jurisdiction In Relation To Joint Criminal Enterprise, 37 (11 May 2004).

18 Prosecutor v. Enver Hadžihasanović, Case No. IT-01-47-PT, Decision on Joint Challenge to Jurisdiction, 62, 165 (12 November 2002); Prosecutor v. Edouard Karemera, et al., Case No. ICTR98-44-T, Decision on the Preliminary Motions by the Defence of Joseph Nzirorera, Édouard Karemera, André Rwamakuba and Mathieu Ngirumpatse Challenging Jurisdiction in Relation to Joint Criminal Enterprise, 37 (11 May 2004).

19 Hadžihasanović, Decision on Joint Challenge to Jurisdiction, supra n. 18, 62 (emphasis added). See also Karemera, et al., Decision on the Preliminary Motions by the Defence of Joseph Nzirorera, Édouard Karemera, André Rwamakuba and Mathieu Ngirumpatse Challenging Jurisdiction In Relation To Joint Criminal Enterprise, supra n. 18, 37 ("Where a principle can be shown to have been so established, it is not an objection to the application of the principle to a particular situation to say that the situation is new if it reasonably falls within the application of the principle.").

${ }^{20}$ Hadžihasanović, Decision on Joint Challenge to Jurisdiction, supra n. 13, 165 (emphasis added).

${ }^{21}$ Case of Streletz, Kessler and Krentz v. Germany, supra n. 12, 105 (finding no violation of the European Convention on Human Right's bar against retroactive application of laws, even though the defendants had been prosecuted under a law that did not exist at the time they committed the acts, because "at the time when they were committed, the applicants' acts... constituted offences defined with sufficient accessibility and foreseeability by the rules of international law on the protection on human rights.")

22 Convention for the Protection of Human Rights and Fundamental Freedoms, Art. 7 Nov. 4, 1950, 213 U.N.T.S. 222, (1953). 
This approach towards the interpretation of the nullum crimen is logical in light of the nature of international law, as explained by one of the Nuremburg Military Tribunals established to prosecute the atrocities of World War II:

Under written constitutions the ex post facto rule condemns statutes which define as criminal, acts committed before the law has passed, but the ex post facto rule cannot apply in the international field as it does under constitutional mandate in the domestic field. [...] International law is not the product of statute for the simple reason that there is yet no world authority empowered to enact statutes of universal application. International law is the product of multipartite treaties, conventions, judicial decisions and customs, which have received international acceptance or acquiescence. It would be sheer absurdity to suggest that the ex post facto rule, as known to constitutional states, could be applied to a treaty, a custom, or a common law decision of an international tribunal, or to the international acquiescence that follows the events. Having attempted to apply the ex post facto principle to judicial decisions of common international law would have been to strangle that law at birth. ${ }^{23}$

Similarly, the ICTY has observed:

Whereas the criminalization process in a national criminal justice system depends upon legislation that dictates the time when conduct is prohibited and the content of such prohibition, the international criminal justice system attains the same objective through treaties or conventions, or after a customary practice of the unilateral enforcement of a prohibition by States. It could be postulated, therefore, that the principles of legality in international criminal law are different from their related national legal systems with respect to their application and standards. ${ }^{24}$

It is therefore relevant to emphasize the strong relationship between the principle of non-retroactivity and the principle that there is no crime or punishment except in accordance with law. However, some authors argue in favor of the making of retroactive laws in exceptional circumstances: in situations where the wrongdoer's acts or omissions were morally wrong, though legal at

23 United States v. Fosef Altstötter, et al., Case No. 3 IMT Trial [Trial of the major war criminals before the International Military Tribunal, Nuremberg], 974-75 (14 November 1945-1 October 1946). It must be noted that the mentioned Military Tribunal was severely criticized for providing for punishment of all crimes against humanity (whether or not in violation of the domestic law of the country where the acts were committed), and for declaring the waging of a war of aggression to be a crime. Both examples were considered to go beyond existing international law. Nevertheless, as mentioned by G. Williams "No injustice was done at Nuremberg, because all the defendants there found guilty were clearly guilty of war crimes in the traditional sense.” See, G. Williams, Criminal Law, The General Part, 577 (1961).

24 Prosecutor v. Zdravko Mucić, Case No. IT-96-21-T, Trial Judgement, 404-05 (16 November 1998). 
Esta revista forma parte del acervo de la Biblioteca Jurídica Virtual del Instituto de Investigaciones Jurídicas de la UNAM

the time when they were committed, that is, when the wrongdoer has transgressed the "natural law". ${ }^{25}$ Such is the case of the previously mentioned Nuremberg Trials for which most jurists have agreed the actions of the Nazis were so immoral as to be an exception to the principle of non-retroactivity. ${ }^{26}$ Yet, even when few would argue that the Nazis found guilty at Nuremberg were treated unfairly or unjustly, they were in fact tried under an ex post facto law, thus ignoring the principle of non-retroactivity.

The scenario brought up in by the Nuremberg trials is that, even when the principle of non-retroactivity is considered a fundamental human right, "retroactive law has been made, and continues to be made, in societies which ostensibly accept that principle as being a [fundamental] right". ${ }^{27}$ This then leads to the interpretation that retro-active law-making is eventually and tacitly accepted.

\section{Blank Griminal Law as a Legislative Tool}

The application of blank criminal law as a legislative technique has been described by the Guatemalan Courts in a very recent decision regarding the initiation of trial against former president Efraín Ríos Montt. ${ }^{28}$ In its decision the Court explained the application of article 378 regarding war crimes and crimes against humanity. This was extended by defining it as a "blank penal law". ${ }^{29}$ Thus, the nature of article 378 as a "blank penal law" serves as a legislative tool, which refers to international covenants or customary laws (jus cogens), where the norm is fully described. ${ }^{30}$ Therefore a legislative tool should be understood as a technique that by the application of a set of rules leads to correct formulation and design of a pre-set norm content, resulting in a juridical-technical harmonization of the norm in itself and with regard to other norms. ${ }^{31}$ Thus, the use of this

25 See, James Popple, The Right to Protection from Retroactive Criminal Law, 4 Criminal Law journal 256 (1989).

${ }^{26} I d$.

27 Id.

28 Audiencia de Resolución de Procedimiento Intermedio, Juzgado Primero de Primera Instancia Penal, Narcoactividad y Delitos Contra el Ambiente por Procesos de Mayor Riesgo (B) Municipio y Departamento De Guatemala. [C.H.R.C] [Courts for High Risk Crimes] (Juez Miguel Angel Galvez Aguilar; 28 January, 2013).

${ }^{29}$ Id. Unofficial translation of: El artículo 378 es una norma penal en blanco... Que por razones de técnica legislativa remite a normas internacionales convencionales o de carácter inderogable, o sea el ius cogens, de donde se hayan sus propuestos de hecho. Transcript of Oral Argument at 19 .

30 Id.

31 Stijn Debaene, Raf van Kuyck and Bea Van Buggenhout, Legislative Technique as Basis of a Legislative Drafting System, in Legal Knowledge Based Systems 23-34 (H. Jaap van den Herik et al. Eds 1999). 
Esta revista forma parte del acervo de la Biblioteca Jurídica Virtual del Instituto de Investigaciones Jurídicas de la UNAM

legislative tool does not collide with the principle of legality: as mentioned by Muñoz Conde and García Aran "once completed, a blank criminal law is as much of a criminal law as any other. From a structural point of view, a blank criminal law does not raise special difficulties, the hypothesis contained in the non-penal norm belongs to the criminal law, integrating or completing it."32

In the case of criminal law Mir Puig explains: "neither the factual situation, nor the legal consequences in criminal law are completely described on any provision stated in the Penal Code. In this sense, all provisions in the Penal Code are individually considered as incomplete propositions". ${ }^{33}$ Therefore, blank criminal laws should not be interpreted as threatening to the principle of legality, except in those cases in which the complementary non-penal law fails to provide a clear description. In that case, both the non-penal and the criminal law would become ineffective. ${ }^{34}$

The application of blank criminal law becomes useful when the subject matter proofs extremely changeable, flexible or complex to be described by a single provision, and therefore demands an immediate reference to another law. ${ }^{35}$ This means that the economy and society are subject to constant evolution. In this sense, the use of such legislative tools becomes necessary. Otherwise, a frequent revision of every prohibited conduct would be necessary to adapt to this constant evolution. ${ }^{36}$

The definition of blank criminal law proposed has been modified through time and inserted into different legal systems. It has been mostly influenced by their particular characteristics and legal standards. Edmund Mezger ${ }^{37}$ would broaden this concept by including two new applications:

32 Unofficial translation of: "la norma penal en blanco, una vez completada, es tan norma penal como cualquier otra. Desde un punto de vista estructural la norma penal en blanco no plantea, por consiguiente, especiales dificultades, el supuesto de hecho consignado en la norma extrapenal pertenece a la norma penal, integrándola o completándola.” FrANCISCO Muñoz Conde \& Mercedes García Arán, Derecho Penal Parte General 36-37 (Tirant lo Blanch, 1996).

33 See, supra n. 3 S. Mir Puig, Derecho Penal Parte General 26 (Barcelona, 1984).

34 See, Luis Miguel Reyna Alfaro, Derecho penal y la ley en blanco. Algunos apuntes sobre la problemática de la técnica del reenvío en las legislaciones penales europeas a propósito de la normativa comunitaria, 41 Themis 327 (2000)

35 Juan Bustos Ramírez, Obras Completas, Derecho Penal, Parte General 387 (Jurídica de Santiago) (2007); Enrique Gury Urzúa, Derecho Penal, Parte General 175 (Universidad Católica de Chile) (2005); Gustavo Cassola Perenzutti, Medio Ambiente y Derecho Penal 29 (B de F) (2005).

36 Id.

37 Mezger, E., Tratado de Derecho Penal; Tomo I 381 (J. A. Rodríguez Muñoz trans., Madrid 2d ed.) (1946) and Edmund Mezger, Derecho Penal. Libro de Estudio. Parte General 154 (Bibliográfica Argentina) (1958), in Ramón Yordanis Alarcón Borges, Normas penales en blanco: Por el camino de la doxa al de la alétheia, Revista Pensamiento Penal, (Jul. 03 2016, 10:12 AM), http://www.pensamientopenal.com.ar/doctrina/29717-normas-penales-blancocamino-doxa-al-aletheia 
Esta revista forma parte del acervo de la Biblioteca Jurídica Virtual del Instituto de Investigaciones Jurídicas de la UNAM

- The supplement to the criminal conduct is described within the same law.

- The supplement to the criminal conduct is described in another law but it emanated from the same body of law. ${ }^{38}$

This addition would then divide the concept of blank criminal law into two: Binding's definition in which the supplement to the described conduct is found in another body of law as a blank criminal law in a strict sense, and Mezger's addition as blank criminal laws in a broad sense. The addition of the two previously mentioned applications should then be interpreted as an external legislative tool. ${ }^{39} \mathrm{It}$ is important to note that in all three applications the necessary supplement is considered as an accessory part of the prohibited conduct. Nevertheless, the whole supplemented prohibited conduct has the same legal effects as any other, specially regarding its significance as a legal base for illegality. ${ }^{40}$

\section{The Application of Blank Criminal Law in Latin America}

The development process and socio-economic transformations that have taken place in Latin America are placing new demands on the exercise of the law. This development not only comes from the field of economics and business but it is also emerging as a reflection from other social needs of particular importance such as the prevention and repression of crime, the protection of the family, and the environment and the protection of certain disadvantaged groups. Moreover, the recent trend towards globalization of national economies and societies is creating new challenges to international law and its application, therefore imposing the internationalization of legal relations and law. ${ }^{41}$

In this context the approach towards the exercise of criminal law in Latin America should rely on appropriate resources to strengthen and also to complement its range of protection, but respecting the limits imposed by the principle of legality or Nullum crimen, nulla poena sine lege. This means that even under the premise of illegality for the application of criminal figures through international law at the domestic level, the use of blank criminal laws serves as an exception to the principle of legality, and therefore opens a channel to include international standards described through covenants and customary international law into domestic systems in the region.

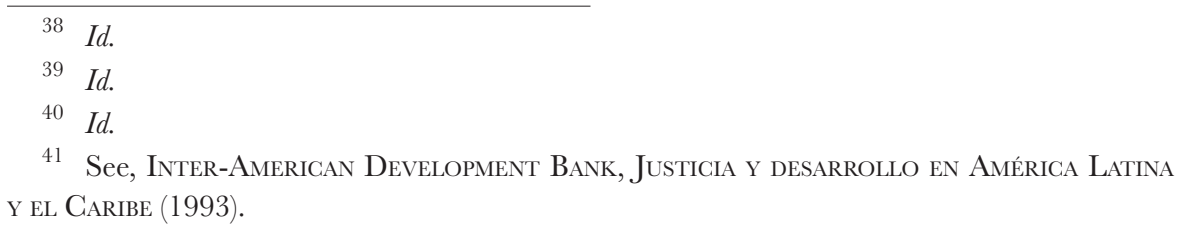


Esta revista forma parte del acervo de la Biblioteca Jurídica Virtual del Instituto de Investigaciones Jurídicas de la UNAM

\section{The Chilean Separation Into Proper, Improper and Open Penal Laws}

The use of blank criminal law in Chile finds its boundaries within its own Constitution, as stated in article 19, section 3, paragraph 8, which reads: "No crime will be punished with a penalty other than that specified by a law promulgated prior to its perpetration, except where a new law favors the affected [person]. No law can establish penalties unless the conduct that [the law] penalizes is expressly described in it. $" 42$

As described through this constitutional provision, the application of blank criminal law is somewhat accepted under the Chilean system. In this sense, the Chilean law uses a similar distinction for blank criminal laws distinguishing them in accordance with their legal status and the hierarchical level of the supplemented prohibited conduct. ${ }^{43}$ Thus, improper criminal laws in blank are those that make a reference to a law in strict sense; proper criminal laws in blank are those that find their supplement in lower legal instruments such as regulations, or any other form of rules emerging from an administrative authority; and finally a third category defined as open penal laws, which are laws with no supplementary law whatsoever, nor lower level regulations to refer to, but its determination or supplement is delivered to the judge. ${ }^{44}$

The Constitutional Tribunal in Chile has tolerated the existence of some blank criminal laws in their proper form. Even when these legal instruments lack a clear description of the prohibited conduct, their reference to a lower level regulation protects them from colliding with the principle of legality. Still, the Court demands three characteristics from the referred law to prevent it from being constitutionally inapplicable:

a. The referred regulation must include the central core of the prohibited conduct;

b. The referring law must clearly state the referring regulation to which it's referring;

c. The referred regulation must provide a certain level of clarity. ${ }^{45}$

42 Unofficial translation of: "Ningún delito se castigará con otra pena que la que señale una ley promulgada con anterioridad a su perpetración, a menos que una nueva ley favorezca al afectado. Ninguna ley podrá establecer penas sin que la conducta que se sanciona esté expresamente descrita en ella" Art. 19, Const. Chile.

43 See, supra no. 2 Álvaro Roberto Delgado Lara, Criminal law in blank in the jurisprudence of the Constitutional Court (2005-2011).

44 See, Sergio Politoff. et al, Lecaiones de Derecho Penal Chileno. Parte General 613 (Editorial Jurídica) (2004); and see Ángela Vivanco, II. Gurso de Derecho Constitucional, Aspectos Dogmáticos de la Carta Fundamental de 1980555 (Universidad Católica de Chile) (2006).

45 Id. 
Esta revista forma parte del acervo de la Biblioteca Jurídica Virtual del Instituto de Investigaciones Jurídicas de la UNAM

The Chilean Tribunal has approached the applicability of blank criminal law by focusing its analysis on the description provided by the original law. ${ }^{46}$ If such description or definition proves insufficient then the legal provision shall be declared unconstitutional. Nevertheless, if the mentioned provision at least describes the central core of the prohibited conduct then other rulings or administrative provisions may supplement it. ${ }^{47}$ This is the case of a proper blank criminal law, which by nature demands a clear and direct reference to the regulations, or any other form of rules emerging from an administrative authority that complements it.

It has been the Tribunal's reasoning that both improper and proper blank criminal laws will always be constitutional. Only in the event that the legal supplement for improper blank criminal laws or any of the previously mentioned characteristics for the proper blank criminal laws are missing, then these will turn into open penal laws. The latter will in fact be considered unconstitutional given that they miss a direct reference to any body of law, thus colliding with the principle of legality. ${ }^{48}$

\section{Argentina and the Mouviel Case}

The distinction between proper and improper blank criminal law has also been studied in Argentina. Criminalist Ricardo C. Núñez distinguishes the first as: those "in which particular infringements are actually designed by the supplementary legal act" ${ }^{\$ 9}$ therefore evading any description of the sanctioned conduct, and so appointing the power to determine the infringement to another law. ${ }^{50}$ Improper blank criminal laws, on the contrary, are those that are limited to sanction certain prohibited conducts on which an specific law or regulation has already ruled. ${ }^{51}$ In these circumstances, even when the prohibited conduct depends on another legislative body, the main law is the one that specifies such conduct, therefore excluding the description in the supplementary law. ${ }^{52}$

Improper blank criminal laws may also be distinguished as those that perform an internal remission within the same law, a different article for ex-

\footnotetext{
46 See, Reguerimiento de Inaplicabilidad por Inconstitucionalidad, Tribunal Constitucional [T.C.] [Constitutional Tribunal] 9 de noviembre de 2006, rol no 468, p. 1 (Chile)

47 See, supra note 34

48 Id.

49 Unofficial translation of: "Las infracciones particulares son creadas, en realidad, por el acto legislativo complementario" in Ricardo G. Nuñez, Manual de Derecho Penal, Parte General 66 (Marcos Lerner) (1999)

$\begin{array}{ll}{ }^{50} & I d . \\ 51 & I d . \\ 52 & I d .\end{array}$
}


ample; while these same laws may perform an external remission to another formal law. ${ }^{53}$ This means that the main law establishes the sanction but then it refers to another article within this same law or to another law at the same hierarchical level to establish the prohibited conduct. ${ }^{54}$

When analyzing the principle of legality in Argentina against the use of blank criminal laws the Mouviel case emerges as an inevitable reference ${ }^{55}$. The case dealt with the arrest of Raúl Mouviel and others for the violation of Police Edicts for public disorders. The defendants were detained for 30 days as determined by the Federal District's Police Chief based on Art. 7 inc. a), of the Argentine Federal Police Statute. The mentioned norm authorized the Police Chief to issue edicts within the competence allocated by the Criminal Procedural Code with the purpose to repress acts of violence that were not considered by the legislator. ${ }^{56}$

The decision was then appealed before the Penitentiary Criminal Judge, who sustained the decision. The defendants made an extraordinary review arguing that the current regime simply concentrated in the Police Chief all three legislative, executive and judiciary powers, which would constitute a violation of the principle of separation of powers. ${ }^{57}$

The Supreme Court reversed the already issued police edicts based on Article18 of the Argentinean Constitution, which clearly states: "No inhabitant of the Nation may be punished without previous trial based on a law enacted before the act that gives rise to the process, nor tried by special committees, nor removed from the judges appointed by law before the act for which he is tried." 58 According to this same reasoning Article 19 states that: "The private actions of men that in no way offend public order or morality, nor injure a third party, are only reserved to God and are exempted from the authority of judges. No inhabitant of the Nation shall be obliged to perform what the law does not demand nor deprived of what it does not prohibit." 59 It is

53 Id.

54 Id.

55 The mentioned case refers to the prosecution of Raúl Mouviel and others for the violation of Police Edicts for public disorders. The defendants were detained for 30 days as determined by the Federal District's Police Chief based on Art. 7 inc. a) of the Argentine Federal Police Statute. The mentioned norm authorized the Police Chief to issue edicts within the competence allocated be the Criminal Procedural Code with the purpose of repressing acts of violence that were not considered by the legislator. See, "Mouviel R. et al." CSJN, FA57000000, 1957.

56 Id.

57 See, Frente Universitario Peronista, caso Mouviel, Resúmenes de Fallos, federación universitaria 8 Blog (May 13, 2016 12:25 PM) http://federacionuniversitaria8.blogspot.com/2008/04/ mouviel.html

58 Unofficial translation of: "Ningún habitante de la Nación puede ser penado sin juicio previo fundado en ley anterior al hecho del proceso, ni juzgado por comisiones especiales, o sacado de los jueces designados por la ley antes del hecho de la causa." Art. 18, Const. Arg.

59 Unofficial translation of: "Las acciones privadas de los hombres que de ningún modo ofendan al orden y a la moral pública, ni perjudiquen a un tercero, están sólo reservadas a Di- 
Esta revista forma parte del acervo de la Biblioteca Jurídica Virtual del Instituto de Investigaciones Jurídicas de la UNAM

thus highlighted that only the legislative power is responsible for establishing, through laws, the description of the prohibited conducts and their corresponding sanctions.

The executive power is, however, entitled to issue "the instructions and rules necessary for the enforcement of the laws of the nation, without altering their spirit with regulatory exceptions". ${ }^{60}$ Nevertheless, the Supreme Court has stated in previous sentences that even if the Executive is granted the power to establish certain police regulations, it means only the faculty to implement regulations that are already defined by the legislature. ${ }^{61}$

In its opinion on the Mouviel case, the Attorney General explains that the reference to another law does not create major problems. ${ }^{62}$ But when the referral from blank criminal laws involves administrative regulations, two situations must be considered: first, if the prohibited conduct is described by criminal law but the description of such conduct must be incorporated with a factual element provided by the Executive, in which case there would be no violation of the principle of legality; and second, if the prohibited conduct is not specified by criminal law but instead it refers to administrative regulations, in which case they should be considered as an example of Article 99.2 of the Constitution. ${ }^{63}$

The Argentinean Constitutional Tribunal therefore considers blank criminal laws admissible only if they meet the following requirements:

- The remission to another regulation must be unavoidable by the complexity or extension of the issue presented.

- The central core must be regulated by the law that it is referring to, while the referred regulation may only verse on secondary issues.

- The referral must be clear and explicit. ${ }^{64}$

\section{The Constitutional Court in Colombia and the Possibility of Sentence Revision}

The principle of legality in Colombia is described under Article 29 of the Constitution as follows:

\footnotetext{
os, y exentas de la autoridad de los magistrados. Ningún habitante de la Nación será obligado a hacer lo que no manda la ley, ni privado de lo que ella no prohíbe". Art. 19, Const. Arg.

${ }^{60}$ Unofficial translation of: "Expide las instrucciones y reglamentos que sean necesarios para la ejecución de las leyes de la Nación, cuidando de no alterar su espíritu con excepciones reglamentarias." Art. 99, Const. Arg.

${ }^{61}$ See, supra note 45.

62 Id.

63 See, supra note 47.

$64 \mathrm{Id}$.
} 
Article 29. Due process will apply to all legal and administrative measures.

No one may be judged except in accordance with the relevant previously written laws before a competent judge or tribunal following all appropriate formalities in each trial.

In penal cases, a permissive or favorable law, even when ex post facto, will be applied with preference over restrictive or unfavorable alternatives.

Every person is presumed innocent until proven guilty according to the law. Everyone criminally charged is entitled to counsel and to chose a defendant or to be appointed one during the investigation and trial; to a fair and public hearing without undue delay; to present evidence and to examine witnesses for the prosecution; to challenge the conviction, and to not be prosecuted twice for the same offence.

Evidence obtained in violation of due process is null and void as of right. ${ }^{65}$

This provision establishes that by Constitutional level, the criminal law must indicate or describe in a complete way the structural elements of the prohibited conduct. In other words, there is no crime if the law has not considered it as such, and this is not accomplished until a clear description and a penalty for it are provided (nullum crimen sine lege-nulla poena sine lege). ${ }^{66}$

The Supreme Court has clearly explained the principle of legality in the following terms:

If the criminal provision appears vague, uncertain, ambiguous or erroneous, those who are called upon to apply it will then be necessarily exercising an arbitrary power, causing an unfair disruption in the sphere of individual liberties, which is inviolable, and Constitutionally guaranteed.

The principle of legality must be aligned with the following essential features of normativity: 1. Every criminal substantial law, whether it constitutes an infraction, a crime, or a disciplinary sanction, must be hierarchically respectful of the Constitution; 2. It must be legally applicable prior to the commission of the crime; 3. It must prove specific, clear, certain, sharp, unequivocal, exhaustive and clearly delimited; 4 . Thus it may not be deemed valid when it appears

65 Unofficial translation of: "El debido proceso se aplicará a toda clase de actuaciones judiciales y administrativas. Nadie podrá ser juzgado sino conforme a leyes preexistentes al acto que se le imputa, ante juez o tribunal competente y con observancia de la plenitud de las formas propias de cada juicio. En materia penal, la ley permisiva o favorable, aun cuando sea posterior, se aplicará de preferencia a la restrictiva o desfavorable. Toda persona se presume inocente mientras no se la haya declarado judicialmente culpable. Quien sea sindicado tiene derecho a la defensa y a la asistencia de un abogado escogido por él, o de oficio, durante la investigación y el juzgamiento; a un debido proceso público sin dilaciones injustificadas; a presentar pruebas y a controvertir las que se alleguen en su contra; a impugnar la sentencia condenatoria, y a no ser juzgado dos veces por el mismo hecho. Es nula, de pleno derecho, la prueba obtenida con violación del debido proceso." Constitución Política de Colombia [Const]. Art. 29. Julio 7 de 1991 (Colombia).

66 See, Claudia Patricia Orduz Barreto, El Principio de Legalidad en la Ley Penal Colombiana, 2 Revista Criterio Jurídico Garantista, (January-June 2010). 
implicit, ambiguous, equivocal, extensive or analogical, with the exception of the latter when it is used to favor the prosecuted ${ }^{67}$.

Under these boundaries, the criminal code in Colombia (Law 599, 2000) provides the following:

Article 6. Legality. No one may be tried except in conformity with the laws that predate the act of which the person is accused, before a competent court or tribunal and in accordance with the procedure appropriate to each case. The preexistence of the law is also applicable for the referral of criminal blank laws. ${ }^{68}$

The Constitutional Court in its Sentence C-559/99 has revised the implementation of blank criminal law in Colombia. ${ }^{69}$ In the Court's reasoning blank criminal laws are characterized by the scope of their prohibition, which cannot be autonomously defined, instead it depends on different provisions of the Law. ${ }^{70}$ The Court finds these legislative tools constitutionally valid if "the remission to another law allows to unequivocally establish the scope of the prohibited conduct and the corresponding sanction". ${ }^{71}$

On a similar matter the Constitutional Court in Colombia used a similar technique as the High Risk Court (A) referring to IHL standards on its

67 Unofficial translation of: "Si la norma penal es vaga, incierta, ambigua o equívoca, los funcionarios llamados a aplicarla resultan detentando por ello solo, necesariamente, un poder arbitrario, y las personas sufrirán el consiguiente recorte injusto en la esfera de la libertad individual inviolable, garantizada por la Constitución".

"El principio de estricta y preexistente legalidad corresponde a los siguientes rasgos esenciales de normatividad: 1 . Toda norma sustancial de naturaleza punible, tanto delictiva, como contravencional, disciplinaria o correccional, debe ser de carácter y jerarquía constitucional o legal, o autorizada por la ley conforme a la Constitución. 2. Debe ser preexistente a la comisión del hecho prescrito como punible y estar vigente al momento que se haya cometido. 3 . Debe ser expresa, clara, cierta, nítida, inequívoca, exhaustiva y de limitativa. 4. No puede por lo tanto adquirirse como válida cuando es implícita, incierta, ambigua, equívoca, extensiva, o analógica, a no ser que respecto de esta última característica, su aplicación sea para favorecer y no para desfavorecer al sindicado o condenado" In: Corte Suprema de Justicia. Sala Plena. (M.P. Fernando Uribe Restrepo; 1o. de septiembre de 1983).

68 Unofficial translation of: "Legalidad. Nadie podrá ser juzgado sino conforme a las leyes preexistentes al acto que se le imputa, ante el juez o tribunal competente y con la observancia de la plenitud de las formas propias de cada juicio. La preexistencia de la norma también se aplica para el reenvío en materia de tipos penales en blanco". Ley 599, 2000. Por la cual se expide el Código Penal. Julio 24 de 2000. DO. No 44.097

69 See, Corte Constitucional de Colombia. Sentencia C-559 de 19994 (M.P. Dr. A. Martínez Caballero; 4 de agosto de 1999).

70 Id.

71 Unofficial translation of: "esas descripciones penales son constitucionalmente válidas, siempre y cuando el correspondiente reenvío normativo permita al intérprete determinar inequívocamente el alcance de la conducta penalizada y de la sanción correspondiente.” In supra no. 59. 
Sentence C-004/03. This decision establishes that it is necessary for the Procedural Criminal Code in Colombia to include the possibility of reopening investigations concerning human rights violations and serious IHL infringements in cases in which the acquittal of a defendant results from a protruding dereliction of the State's duty to investigate, these behaviors in a serious and impartial manner. ${ }^{72}$ Article 220 concerning revision causes does not include that provision. So the code has a legislative gap. The Court resolves this situation by determining the nature of the crimes added to the State's obligation to prosecute these crimes. Therefore, such gap should and must be filled through a sentence that integrates the possibility to revise those cases involving the rights of human rights victims as grave breaches to IHL. ${ }^{73}$

The Constitutional Court in Colombia determines that Article 220 may be invoked in the revision of cases of preclusion of investigation, cessation of proceedings or dismissal of charges, in which human rights violations or serious IHL infringements are involved, and a domestic court judgment or a decision by an international human rights monitoring and follow-up body, formally recognized by Colombia, has found that there exists a new fact or evidence not known at the time of the hearing. ${ }^{74}$ In this sense, it is the duty of the judge in Colombia to abide by such possibility even when it's not literally expressed in the Criminal Code.

\section{Costa Rica and the Immediate Reference to International Law}

The inclusion of international crimes as a particular prohibition within the criminal normativity in Costa Rica provides a more tolerant application of blank criminal laws in the State. Thus in alignment with the principle of legality as defined by its Constitution where it states: "Article 28. No one may be disturbed or persecuted for expressing his opinions or for any act that does not infringe the law." ${ }^{75}$ Article 374 of Costa Rican Penal Code states the following:

Crimes of international level: Article 374. For those who direct or take part in international organizations with the purpose of trafficking slaves, women or children, drugs, or [those who] carry out acts of terrorism, or infringe human rights treaty provisions ratified by Costa Rica, the penalty shall be a term between ten to fifteen years' imprisonment. ${ }^{76}$

72 See, Corte Constitucional de Colombia, Sentencia C-004 de 200334 (M.P. Dr. Eduardo Montealegre Lynett; 20 de enero de 2003).

73 Id.

74 Id.

75 Unofficial translation of: "Nadie puede ser inquietado ni perseguido por la manifestación de sus opiniones ni por acto alguno que no infrinja la ley.” C. Rica Const. Art. 28 (1949)

76 Unofficial translation of: "Delitos de carácter internacional: ARTÍCULO 374. Se impondrá prisión de diez a quince años a quienes dirigieren o formaren parte de organizaciones 
Under this provision, it becomes clear that Costa Rica easily abides by the principle of legality without the use of an exhaustive description of the criminal conduct. Although, it seems valid to state that the allusion to this type of blank criminal laws directs to figures provided by conventional standards, consideration must be given the fact that criminal law will not be sufficiently covered by the mere reference to crimes described by customary international law. The exercise of customary international law demands a widespread and constant practice by the State and its correspondent opinio iuris. ${ }^{77}$ Nonetheless, Costa Rica's use of criminal laws in blank provides an interesting reference to international law as a complement to its own description of criminal conducts. As it will be explained below, Guatemala uses a very similar technique for the implementation of international conventional standards and customary international law into its own criminal system.

The Constitutional Court in Costa Rica has found that the application of blank criminal laws is constitutionally acceptable as long as the referral carried out by the law is done towards a provision at the same level. Thus, sentence 6785-05 stated the following:

...in the particular case, what the appellant states is that the criminal conduct attributed to him, as detailed in Article 213 of the Criminal Code, is incomplete. Therefore to be deemed understandable and applicable it must be supplemented by Article 209 of the same law. This Court has previously ruled in favor of the constitutionality of such specific legislative technique [blank criminal laws], which is used to complement legal standards in order to configure and complete all the minimum necessary elements of the offense. ${ }^{78}$

Under the Court's analysis the contested law is fully constructed by all the required elements for a criminal conduct: the active subject, the description of the conduct, and the sanction for it, and then it does not prove illegal in the light of the principle of legality. ${ }^{79}$

de carácter internacional dedicadas a traficar con esclavos, mujeres o niños, drogas estupefacientes o realicen actos de terrorismo o infrinjan disposiciones previstas en los tratados suscritos por Costa Rica para proteger los derechos humanos”. Cod. Pen. Art. 374 (C. Rica 1970)

77 See, X FERnÁndez Pons, "El principio de legalidad penal y la incriminación internacional del individuo" 5 REEI, 8 (2002).

78 Unofficial translation of: "Ahora bien, en el caso particular, lo que el recurrente señala es que el tipo penal que se le aplicó, contenido en el artículo 213 del Código Penal está incompleto y para ser entendible y aplicable debe completarse con el artículo 209 del mismo cuerpo normativo. Ya este órgano se ha pronunciado a favor de la constitucionalidad de este tipo de técnica legislativa específica consistente en emplear normas de rango legal para que se complementen entre ellas con miras a configurar y completar todos los elementos mínimos necesarios del tipo penal. In: Corte Constitucional de Costa Rica, Sentencia 6785 de 2005.

79 Id. 


\section{The Principle of Nullum Crimen Under Guatemalan Domestic Law}

The principle of legality is also firmly rooted in Guatemalan law. For instance, Article 5 the Constitution provides: "All persons have the right to do what the law does not prohibit; [the persons] are not obligated to obey orders that are not based in law or issued in accordance to it. Neither may they be persecuted or harassed for their opinions or for acts that do not imply an infraction of it." ${ }^{80}$ Furthermore, Article 17 of the Constitution provides: "The actions or omissions that are not qualified as crimes or faults and that [are] punishable by a law [that is] prior to their perpetration[,] are not punishable. $^{81}$

80 Unofficial translation of: "Toda persona tiene derecho de hacer lo que la ley no prohíbe; no está obligada a acatar órdenes que no estén basadas en ley y emitidas conforme a ella. Tampoco podrá ser perseguida ni molestada por sus opiniones o por actos que no impliquen infracción a la misma” Guat. Const. Art. 5 (1985)

81 Unofficial translation of: "No son punibles las acciones u omisiones que no estén calificadas como delito o falta y penadas por ley anterior a su perpetración.” Guat. Const. Art. 17 (1985). See also Corte de Constitucionalidad de Guatemala, Expediente 1122 de 2005 (1 de febrero de 2006). The mentioned sentence also argues "Article 17 of the Guatemalan Constitution states that actions or omissions that are not qualified as crimes or faults and that [are] punishable by a law [that is] prior to their perpetration[,] are not punishable. This principle, which is also a guarantee for a prosecution under the legal principle of due process, is one of the central elements of the criminal prosecution in a democratic society, and imposes an obligation to the common legislator to define, as clear as possible (lex certa) [,] which of those conducts that may be punishable through the determination of the criminal offences that include a clear definition of the criminalized conduct, narrow its elements to allow a clear distinction between conducts of a criminal nature and those which are not.") (Unofficial translation of: "El artículo 17 de la Constitución Política de la República de Guatemala expresa que no son punibles las acciones u omisiones que no estén calificadas como delito o falta y penadas por ley anterior a su perpetración. Este principio, que a su vez constituye una garantía para un juzgamiento conforme al principio jurídico del debido proceso, constituye uno de los elementos centrales de la persecución penal en una sociedad democrática, e impone la obligación al legislador ordinario de definir en la forma más clara y precisa posible (lex certa) cuáles son esas "acciones u omisiones" que son consideradas punibles mediante la determinación de tipos penales que contemplen una clara definición de la conducta incriminada, concretizar sus elementos y permitir así deslindar conductas punibles de aquellas que no lo son."). The principle is also mentioned in Article 1 of Guatemala Penal Code: "No one shall be punished for acts that are not expressly qualified as crimes or offenses by law prior to their perpetration; no penalties different to those previously established by law will be imposed." Unofficial translation of: "Nadie podrá ser penado por hechos que no estén expresamente calificados, como delitos o faltas, por ley anterior a su perpetración; ni se impondrán otras penas que no sean las previamente establecidas en la ley." Likewise, Article 1 of the Guatemalan Penal Procedure Code states: "No punishment shall be imposed if the law has not [been] defined it in advance." Unofficial translation of: "No se impondrá pena alguna si la ley no la hubiere fijado con anterioridad." Finally, Article 2 of the Penal Procedure Code states: "No trial, complaint or grievance process may be initiated but by conducts qualified as crimes or offenses by a previous law. Without this prerequisite, proceedings shall be deemed null and may induce the Court's accountability." 
While the Guatemalan Constitutional Court has held that nullum crimen "demands that the criminal conduct is fully described in the positive law," this requirement does not preclude the prosecution of acts that were criminalized only as a matter of customary international law at the time they were committed. ${ }^{83}$ Article 149 of the Guatemalan Constitution expressly incorporates customary international law as part of domestic law insofar as it governs its international relations in accordance with international principles, rules and practices. ${ }^{84}$ This means that a rule of international law can be enforced without being enacted by Congress. This is only valid if the existence and extent of a certain rule of international law has been duly proven to be binding and accepted by the international community as a whole, and if it has never been rejected by the State under consideration..$^{85}$

However, the Court's reasoning in a case involving allegations of torture as a war crime leads to a contradiction against this provision when it states:

Resorting to international norms cannot restore the vulnerable condition of such criminal acts regarding torture (or any other crime under IHL), even if they are norms of ius cogens that demand universal application. Regarding the principle of legality, as referred in the preceding paragraphs, for a criminal offense to be linked with the commission of criminal acts, it must be fully described within a norm, otherwise it would violate the freedom of will granted to

Unofficial translation of: "No podrá iniciarse proceso ni tramitarse denuncia o querella, sino por actos u omisiones calificados como delitos o faltas por una ley anterior. Sin ese presupuesto, es nulo lo actuado e induce responsabilidad del tribunal."

${ }^{82}$ See, Corte de Constitucionalidad de Guatemala, Inconstitucionalidad General Parcial por omisión, Expediente 1822-2011, 20 (17 de julio de 2012). In this mentioned sentence the Constitutional Court of Guatemala addressed the issue of the definition of Torture found in Article 201 bis of the Penal Code. According to the sentence, the former definition of Torture was inconsistent by omission with international standards since the mentioned definition failed to include the objective element of the acts committed "based on discrimination of any kind", as stated on article 1 of the Convention against Torture and Other Cruel, Inhuman or Degrading Treatment or Punishment which the Guatemalan congress ratified through decree 58-95 on 10 August 1995. And the use of methods upon a person intended to obliterate the personality of the victim or to diminish his physical or mental capacities, even if they do not cause physical pain or mental anguish, as described on the Inter-American Convention to Prevent and Punish Torture, to which Guatemala is a State Party since December 121986. Unofficial translation of: Adviértase que, en cuanto a la razón de la inconstitucionalidad examinada, se hace referencia a un precepto del Código Penal, que no puede ser suplido por vía de interpretación ni por analogía, puesto que el principio de legalidad penal exige que el tipo a sancionar sea debidamente establecido en el derecho positivo.

83 See, Ana Cristina Rodríguez Pineda, Guide to Legal Research in Guatemala, Section. 4.2.2, (Jul. 23, 2016, 11:15 AM), http://www.nyulawglobal.org/globalex/Guatemalal. html\#_4.2_Treaties

${ }_{85}^{84} I d$. 
the State's citizens, particularly taking into account the prohibition of analogy and broad interpretation embodied in criminal law. ${ }^{86}$

The Court goes further to state: "for this reason, the prohibited conduct must be concrete. If the qualifying elements for this conduct are not reached, then the constitutional parameters for the creation of offenses will not be met." $" 87$

Given the forgoing, it is clear that, to be prosecuted in Guatemala, an act must have been criminalized either under the domestic law applicable in the State or under international law at the time it was committed. The charges in the Sepur Zarco case have been brought under Article 378 of the Guatemalan Penal Code, which states: Crimes against the Duties of Humanity: Whosoever violates or infringes humanitarian obligations, laws or covenants regarding prisoners or hostages of war or those wounded in battle, or whosoever commits any inhuman act against the civilian population or against hospitals or places designated for the wounded will be sentenced to $20-30$ years in prison. ${ }^{88}$

While this provision clearly criminalizes violations of international humanitarian law, it does not "fully describe[s]" the individual violations that fall within its scope, as required by the Guatemalan Constitutional Court in its analysis of the principle of legality cited above. ${ }^{89}$ Nevertheless, the accused in the present case were charged with crimes against the duties of humanity in the specific forms of sexual violence, sexual slavery, domestic slavery, and outrages upon personal dignity. ${ }^{90}$ Indeed, during the stage of proceedings intended to determine whether there is a basis for committing a person to trial, the First Instance Judge, Miguel Ángel Gálvez, permitted the case to go to trial against the accused on the basis of these specific charges, arguing, in part, that Article 378 is an open or "blank, criminal law," meaning that although it does not describe in detail the conduct proscribed, it makes reference to

86 Unofficial translation of: "La desprotección de tales actos en el tipo penal de la tortura no puede suplirse acudiendo a las normas internacionales, pues aunque son normas de ius cogens que son de aplicación universal, con base en el principio de legalidad, tal como se refirió en párrafos precedentes, para que un tipo penal pueda ser aplicado a la comisión de hechos delictivos, debe ser plenamente descrito en una norma, pues de lo contrario, violaría la libertad de acción de la que gozan los ciudadanos del país, tomando en cuenta la prohibición de analogía y de interpretación extensiva que opera en materia penal.” in supra note 72.

87 Unofficial translation of: "razón por la que la conducta prohibida debe ser concreta, porque si no se consignan íntegramente los elementos específicos del supuesto de hecho, no se cumplirían con los parámetros constitucionales para la creación de los delitos." Id.

88 Unofficial translation of: "Quien violare o infringiere deberes humanitarios, leyes o convenios con respecto a prisioneros o rehenes de guerra, heridos durante acciones bélicas, o que cometiere cualquier acto inhumano contra población civil, o contra hospitales o lugares destinados a heridos, será sancionado con prisión de veinte a treinta años." Cód. Pen. Art. 378 (Guat. 1973).

89 See supra Note. 70.

90 See, supra Note. 2.

91 Juzgado Primero de Primera Instancia Penal, Resolución de Fase Intermedia, supra, 28. 
other sources of law and allows a court to define the proscribed conduct by reference to those other sources. ${ }^{92}$ Judge Gálvez explained that the Penal Code, which Guatemala adopted in 1976, created various offenses of international concern, among them Article 378, which "of course refers us to international conventions and especially the [1949] Geneva Conventions" ratified by Guatemala in 1952. ${ }^{93}$ Noting that the provision had to be interpreted in light of developments in international law, Judge Gálvez went on to point out that, Article 378 was intended to refer not only to war crimes but also to crimes against humanity. ${ }^{94}$ Thus, under Article 378 of the Guatemalan Penal Code, this court has jurisdiction to adjudicate acts constituting crimes under customary or conventional international law binding on Guatemala.

\section{Conclusion}

Though useful, the legislative tool of blank criminal law finds a certain level of resistance within the legal systems reviewed. It is a common understanding that such a tool can only be exercised as an exception to heavily positivized legal systems. For this reason States like Chile and Argentina opt for strict applications of blank criminal laws in only allowing the reference they provide through rulings of lower hierarchical level. On the other hand, States like Costa Rica and Guatemala use blank criminal laws as a more open reference to notably complex subjects like International Humanitarian Law and customary international law. On either approach, it becomes important to bring to attention the thoughts of Luis Miguel Reyna when he states that blank criminal laws do not particularly interfere with the principle of legality, except only in those cases in which the non-penal law makes an unclear description of the criminal conduct. ${ }^{95}$

92 See Impunity Watch, Monitoreo de la Justicia Transicional en Guatemala, Tomo II: Derecho a la justicia para las víctimas del Conflicto Armado Interno 16, (Jul. 23, 2016, $11: 43$ AM), http://www.impunitywatch.org/docs/Research_report_informe_monitoreo_IW_JUSTICIA_Dec_2014.pdf (internal citations omitted).

93 Juzgado Primero de Primera Instancia Penal, Resolución de Fase Intermedia, supra n. 28.

94 Id. Notably, this position is consistent with that of other experts. See, e.g. Impunity Watch, supra n. 92 ("En efecto, los crímenes de guerra, los crímenes de lesa humanidad, y el genocidio, que están categorizados como delitos internacionales, se encuentran previstos en el CP guatemalteco (lex scripta). Por razones técnicas se afirma que los crímenes de guerra y de lesa humanidad están amparados en el artículo 378, puesto que los elementos y sub-conductas tipo de tales delitos permiten su integración en una sola disposición legal, ya que para identificarlos necesariamente hay que recurrir a los tratados internacionales pertinentes ratificados por Guatemala. Además, tanto los delitos contra los deberes de humanidad como el genocidio forman parte del Capítulo IV (De los delitos de trascendencia internacional) que incluye los tipos penales que ofenden al mundo entero y responde a obligaciones internacionales adquiridas por el Estado.").

95 See, supra note 34 Luis Miguel Reyna Alfaro, Derecho penaly la ley en blanco. Algunos apuntes sobre la problemática de la técnica del reenvio en las legislaciones penales europeas a propósito de la normativa comunitaria. 
Nevertheless, it is also notable how the use of blank criminal law has become a more frequent trend starting in the nineties to the date. With the exception of Argentina, the use of blank criminal laws has become a more recent approach by the reviewed States. The period coincides with the transition of these legal systems from complex situations of human rights violations towards the inclusion of human rights standards into their legal orders. This period includes the ending of the Military dictatorship in Chile in 1989; the demobilization of the M-19 guerrilla and the new Constitution signed in 1991 in Colombia, and, the peace process in Guatemala in 1996. These transitions where followed by a strong implementation of International Human Rights Law and International Criminal Law into their legal systems.

It appears that the complexity and length of the mentioned bodies of law proved difficult enough for this States to handle. Then, the use of legal tools as criminal laws in blanks serves as a practical way to resolve this. Nevertheless, the requirements the nulla poena sine lege demands, proves that regardless of the legislative tool chosen by each State, the existence of an internal law which in some way translates the international standards for international crimes, becomes necessary.

In other words, the use of legislative tools such as blank criminal law may be understood as the fulfillment of the State's obligation to "adopt, in accordance with their constitutional processes and the provisions of this Convention, such legislative or other measures as may be necessary to give effect to" ${ }^{\text {96 }}$ the rights and freedoms described by the relevant covenant. In the words of the Permanent Court of International Justice: "a State which has contracted valid international obligations is bound to make in its legislation such modifications as may be necessary to ensure the fulfillment of the obligations undertaken." 97

As mentioned above, the decision regarding the conviction of two former Military men in Guatemala constitutes the first case in which a local Court tries and sentences individuals for crimes against humanity and war crimes. Notably, the decision was taken making an strict reference to blank criminal laws that might not appear as popular within the region. However, its application is positive for convictions like these.

It is not unfair to say that the Guatemala case has become an example for the enactment of IHL provisions throughout the region, not only for undertaking the necessary measures, but most importantly for bringing such measures to the highest level of practice.

96 American Convention on Human Rights, art. 2, Nov. 22, 1969, O.A.S.T.S. No. 36, 1144 U.N.T.S. 123 Such obligation is also stated by the Convention on the Prevention and Punishment of the Crime of Genocide. Which states in Article 5: "The Contracting Parties undertake to enact, in accordance with their respective Constitutions, the necessary legislation to give effect to the provisions of the present Convention and, in particular, to provide effective penalties for persons guilty of genocide or any of the other acts mentioned in Article 3."

97 Exchange of Greek and Turkish Populations (Greece v Turkey), Advisory Opinion, PCIJ Series B no 10, at 20 ICGJ 277 (1925). 